\author{
Departement für Pferde \\ Klinik für Pferdechirurgie \\ der Vetsuisse-Fakultät Universität Zürich
}

Direktor: Prof. Dr. med. vet. Anton Fürst

Arbeit unter wissenschaftlicher Betreuung von: Dr. med. vet. Andrea Bischofberger

\title{
Fixation of supraglenoid tubercle fractures using distal femoral locking plates in 3 Warmblood horses
}

\author{
Inaugural-Dissertation
}

zur Erlangung der Doktorwürde der Vetsuisse-Fakultät Universität Zürich

\author{
vorgelegt von \\ Sina Sarah Frei \\ Tierärztin \\ aus Kloten, Zürich \\ genehmigt auf Antrag von \\ Prof. Dr. med. vet. Anton Fürst, Referent
}




\section{Inhaltsverzeichnis}

Summary EN 1

Zusammenfassung DE 2

Fixation of supraglenoid tubercle fractures using distal femoral

locking plates in 3 Warmblood horses

Published in Vet Comp Orthop Traumatol 2016, 29: 246-252,

Frei, Fürst, Sacks and Bischofberger

Danksagung

Curriculum vitae 


\section{Summary EN}

Three horses that were presented with supraglenoid tubercle fractures were treated with open reduction and internal fixation using distal femoral locking plates (DFLP). Placing the DFLP caudal to the scapular spine in order to preserve the suprascapular nerve led to a stable fixation, however, it resulted in infraspinatus muscle atrophy and mild scapulohumeral joint instability (case 1). Placing the DFLP cranial to the scapular spine and under the suprascapular nerve resulted in a stable fixation, however, it resulted in severe atrophy of the supraspinatus and infraspinatus muscles and scapulohumeral joint instability (case 2). Placing the DFLP cranial to the scapular spine and slightly overbending it at the suprascapular nerve passage site resulted in the best outcome (case 3). A mild degree of supraspinatus and infraspinatus muscle atrophy was apparent, which resolved and with no effect on scapulohumeral joint stability. In all cases, fixation of supraglenoid tubercle fractures using DFLP in slightly different techniques led to stable fixations with good long-term outcome. One case suffered from a mild incisional infection and plates were removed in two horses. Placement of the DFLP cranial to the scapular spine and slightly overbending it at the suprascapular nerve passage prevented major nerve damage. Further cases investigating the degree of muscle atrophy following the use of the DFLP placed in the above-described technique are justified to improve patient outcome.

Keywords: Scapula, supraglenoid tubercle fractures, distal femoral locking plates, suprascapular nerve 


\section{Zusammenfassung DE}

Drei Pferde, welche eine Fraktur des Tuberculum supraglenoidale erlitten, wurden mittels offener Reduktion und interner Fixation mit einer distalen Femur-Verriegelungsplatte chirurgisch versorgt. Beim ersten Pferd wurde die Platte kaudal der Spina scapulae positioniert und es konnte eine stabile Fixation erreicht werden, obwohl eine Atrophie des M. infraspinatus und eine leichtgradige scapulohumerale Gelenksinstabilität auftrat (Fall 1). Wenn die Platte kranial der Spina scapulae und unter dem N. suprascapularis positioniert wurde, konnte ebenfalls eine stabile Fixation erreicht werden, es trat aber eine hochgradige Atrophie des M. supraspinatus und M. infraspinatus und infolgedessen eine scapulohumerale Gelenksinstabilität auf (Fall 2). Beim dritten Pferd wurde das beste Ergebnis erreicht, indem die Platte kranial der Spina scapulae und über dem Nerv leicht aufgebogen positioniert wurde (Fall 3). Es trat eine leichte, vorübergehende Nervenschädigung ohne Instabilität des Schultergelenks auf. Bei den drei Pferden konnte durch die Anwendung dieser Platte, eine stabile Fixation mit einem guten Resultat erreicht werden. Bei einem Pferd trat postoperativ eine leichtgradige Infektion der Naht auf. Bei zwei Pferden wurde die Platte wieder entfernt. Weitere Studien sind nötig, um die Auswirkung der Anwendung dieser Platte auf das Ausmass der Muskelatrophie zu bestimmen.

Schlüsselwörter: Scapula, Frakturen des Tuberculum supraglenoidale, distale FemurVerriegelungsplatte, N. suprascapularis 


\section{Fixation of supraglenoid tubercle fractures using distal femoral locking plates in 3 Warmblood horses}

S. Frei ${ }^{1}$, A.E. Fürst ${ }^{1}$, M. Sacks ${ }^{2}$, A.S. Bischofberger ${ }^{1}$

Clinic for Equine Surgery ${ }^{1}$, Section of Anesthesiology ${ }^{2}$, Equine Department, Vetsuisse Faculty, University of Zürich, Winterthurerstrasse 260, CH-8057 Zürich, Switzerland. 


\section{Introduction}

Supraglenoid tubercle fractures are common in young horses. They are usually simple, intraarticular, apophyseal fractures with cranio-ventral displacement of the fracture fragment (1-4). These fractures are usually the result of direct trauma to the point of the shoulder or are avulsion fractures caused by tension of the biceps and coracobrachialis tendon, which originate at the supraglenoid tubercle $(1,4-6)$. The majority of cases are young horses which may be due to the apophyseal separation of the supraglenoid tubercle. Although the apophysis fuses with the metaphyseal bone by 10-12 months of age, later in life it may still represent a weak point of this bone region (5-7).

The suprascapular nerve is a large nerve which arises from the sixth and seventh cervical spinal cord nerve roots, and passes between the supraspinatus and subscapular muscles over the cranial margin of the scapula laterally, just distal to the point of the scapular spine and it ramifies in the supraspinous and infraspinous fossae (4). The suprascapular nerve innervates the supraspinatus and infraspinatus muscles, which provide lateral support to the shoulder. There are several options for the management of supraglenoid tubercle fractures.

Conservative therapy alone for all, but the smallest supraglenoid tubercle fractures, is not adequate to successfully return a horse to athletic soundness, although they may become pasture sound (6). When the supraglenoid tubercle fracture fragment is resected, fibrous union leads to re-attachment of the biceps tendon not far from the anatomical site, but degenerative joint disease and mechanical obstruction may result in lameness $(1,8)$. After resection of the supraglenoid tubercle fracture fragment, horses may reach pasture soundness, and some may be able to engage in some level of athletic activity (9). Surgical intervention should focus on restoring articular congruity of the glenoid cavity to prevent osteoarthritis and on neutralizing the tension from the bicipital apparatus (3). Surgical fixation can be achieved with lag screws, or pins and tension band wiring $(1,9,11)$. Partial or full biceps tenotomy in conjunction with internal surgical fixation may prevent tension on the fracture repair $(3,12)$. Fracture repair has been associated with complications and limited success in large and heavy horses, which has been attributed to the poor screw holding quality of the scapula, difficulty in fracture reduction and restoration of the articular surface as well as failure of the fixation due to the pull of the bicipital apparatus (1).

Distal femoral locking plates ${ }^{\mathrm{a}}$ (DFLP) are used in humans for the management of fractures of the distal femoral shaft and fractures close to or involving joints (13-18). The shaft of the plate consists of a variable number of Combi holes (5-19). A plate with a shaft of five holes is 
$156 \mathrm{~mm}$ long and a plate with a shaft of seven holes is $196 \mathrm{~mm}$ long. The thickness of the plate is $5 \mathrm{~mm}$ at its shaft and $2 \mathrm{~mm}$ at its head. The head of the plate contains seven Combi holes, concentrated in a fairly small area (Figure 1). The plate is available in stainless steel or titanium and designed as right- or left-sided, to fit the human femoral shape. The plate is used in locking compression plate (LCP) fashion.

The aim of this report was to describe the surgical technique that was used in 3 cases of supraglenoid tubercle fractures repaired with DLFP placed in different positions as well as report the complications and the outcome. We proposed that use of DFLP for the fixation of supraglenoid tubercle fractures would be ideal because the head of the plate would allow the concentration of multiple screws in the fracture fragment of the supraglenoid tubercle.

\section{Case 1}

A 1.5-year-old, 350kg Warmblood colt was referred to the Equine Hospital at the University of Zurich for the repair of a 3 day old, simple, left, mildly cranio-ventrally displaced, articular fracture of the ST fracture (Figure 2).

\section{Case management}

Cefquinom $^{\mathrm{b}}(1 \mathrm{mg} / \mathrm{kg}$ IV $)$, phenylbutazone $\mathrm{c}^{\mathrm{c}}(4.4 \mathrm{mg} / \mathrm{kg} \mathrm{IV})$ and acepromazine $\mathrm{d}^{\mathrm{d}}(0.03 \mathrm{mg} / \mathrm{kg}$ IM) were administered 30 minutes prior induction of anesthesia. The colt was sedated with medetomidine $^{\mathrm{e}}(7 \mathrm{mcg} / \mathrm{kg} \mathrm{IV})$ and anesthesia was induced with ketamine ${ }^{\mathrm{f}}(2.2 \mathrm{mg} / \mathrm{kg} \mathrm{IV})$ and diazepam $^{\mathrm{g}}(0.02 \mathrm{mg} / \mathrm{kg} \mathrm{IV})$. Anesthesia was maintained with isoflurane ${ }^{\mathrm{h}}$ in oxygen and air, as well as a constant rate infusion of medetomidine $\mathrm{e}^{\mathrm{e}}(3.5 \mathrm{mcg} / \mathrm{kg} / \mathrm{h} \mathrm{IV})$. Routine anesthetic monitoring was performed. Adequate blood pressure was maintained by administration of dobutamine $^{\mathrm{i}}(<1.25 \mathrm{mcg} / \mathrm{kg} / \mathrm{min} \mathrm{IV})$, lactated Ringer`s solution ${ }^{\mathrm{j}}(10 \mathrm{ml} / \mathrm{kg} / \mathrm{h} \mathrm{IV})$ and hetastarch $10 \%^{\mathrm{k}}(6 \mathrm{ml} / \mathrm{h} \mathrm{IV})$. The colt was placed into right lateral recumbency for surgery. A $20 \mathrm{~cm}$ curved skin incision was made, starting at the distal extent of the scapular spine, curving over the major tubercle of the humerus and continuing distally to the deltoid tubercle of the radius. The brachiocephalicus and supraspinatus muscles were separated and the brachiocephalicus muscle retracted cranially. The supraspinatus muscle was incised parallel to its fiber alignment over the fracture and separated with self-retaining retractors. The fracture line was identified and the fractured bone ends were debrided. The suprascapular nerve was also identified and preserved. The ST was grasped with bone reduction forceps and the fracture reduced by manipulation of the limb in extension and flexion and by the use of 
pointed reduction forceps as temporary fixation. A left-sided DFLP ${ }^{\mathrm{a}}$ with a 5-hole-shaft was contoured, slightly bent and placed caudal to the scapular spine and onto the cranial aspect of the supraglenoid tubercle. The plate was fixed with $85 \mathrm{~mm}$ locking head screws. Four were positioned in the plate head engaging the supraglenoid tubercle fracture fragment and four in the plate shaft engaging the scapula (Figure 3). The surgical incision was closed in three layers. The surgical site was covered with two self-adhesive iodine impregnated drapes ${ }^{1}$ fixated with adhesive spray glue ${ }^{\mathrm{m}}$. These were covered by self-adhesive elastic bandages ${ }^{\mathrm{n}}$ attached with skin staples ${ }^{\mathrm{o}}$ and covered with vaseline ${ }^{\mathrm{p}}$ to prevent water from contaminating the incision during recovery from general anesthesia in the hydropool system. Twenty minutes before the end of anesthesia morphine ${ }^{\mathrm{q}}(0.1 \mathrm{mg} / \mathrm{kg} \mathrm{IM})$ was administered. Sedation with medetomidine ${ }^{\mathrm{e}}(2 \mathrm{mcg} / \mathrm{kg} \mathrm{IV})$ was provided while the horse was in the pool.

Postoperatively, the colt was confined to a box stall and treated with phenylbutazone ${ }^{\mathrm{r}}(2.2$ $\mathrm{mg} / \mathrm{kg}$ PO BID for 9 days and PO SID for 6 days). Cefquinom ${ }^{\mathrm{b}}$ ( $1 \mathrm{mg} / \mathrm{kg}$ IV BID) was administered for 10 days followed by trimethoprim sulfonamide ${ }^{\mathrm{s}}$ (30 mg/kg PO BID) for six days. A hoof bandage with frog support was applied to the contralateral limb to prevent laminitis.

Five days postoperatively, the colt was poorly weight bearing on the left forelimb. The incision site was slightly warm and oedematous, but there was no evidence of drainage. Treatment with antibiotics and anti-inflammatory medications was continued; the swelling resolved and the weight bearing improved. Twenty-two days postoperatively the colt was only mildly lame at the walk on the left forelimb, however atrophy of the infraspinatus muscle and a mild scapulohumeral joint instability had become apparent. Radiographs of the left shoulder revealed signs of good progression of fracture healing, determined by the fracture gap being less visible, and also there was no evidence of lysis around the screws, screw loosening, or implant failure. The colt was discharged and the owner was instructed to confine the colt to a box stall for further two months and to start hand walking daily. Follow up radiographs were recommended after two months.

\section{Follow-up and outcome}

Two and a half years postoperatively, the gelding was re-presented because of a mild left forelimb lameness at a trot and a mild atrophy of the infraspinatus muscle. Medio-lateral radiographs of the shoulder revealed a healed supraglenoid tubercle fracture with stable implants and evidence of mild osteoarthritis of the shoulder joint. Ultrasonographically, signs of hypoechoic tissue that was probably fibrous or fat tissue embedding the plate were visible. 
The plate was partially embedded into the supraspinatus muscle. The supraspinatus muscle and tendon, passing distal to the plate had a heterogeneous appearance consistent with a chronic myopathy or tendinopathy, possibly due to plate placement. The biceps tendon was of normal heterogeneity and the bicipital bursa was without effusion. New bone formation was visible at the shoulder joint consistent with osteoarthritis. It was elected to remove the plate while the horse was standing and sedated. At the distal aspect of the plate, a round-shaped, yellow tissue was removed and submitted to histopathology. The histological examination was consistent with connective tissue, most likely the formation of scar tissue. The horse was kept in a sling ${ }^{\mathrm{v}}$ for 10 days to prevent incisional dehiscence. The gelding was discharged from the hospital after 17 days. The owner was given instructions to hand walk the gelding for one month, followed by two months of walk with short trot periods. No free pasture access was allowed for three months. Radiographic examination by the private veterinarian at two months was recommended.

One month after implant removal the gelding was sound at a walk, but still showed a mild left forelimb lameness at a trot; the infraspinatus muscle atrophy was still slightly present, however the owner was satisfied with the progress.

\section{Case 2}

A 10.5-year-old, $500 \mathrm{~kg}$ Warmblood gelding was referred to the Equine Hospital at the University of Zurich for the repair of a three day old, simple, mildly cranio-ventrally displaced, articular fracture of the right supraglenoid tubercle.

\section{Case management}

Pre-medication, preoperative preparation, the anesthetic protocol, and the fracture approach were as described in case 1 . The gelding was placed into left lateral recumbency for the surgery. The suprascapular nerve was identified running over the neck of the scapula; it was gently isolated and raised from the surrounding tissue using a narrow Penrose drain. The fracture was reduced using bone reduction forceps and a left-sided 5-hole-DLFP ${ }^{\mathrm{a}}$ was contoured and placed cranially to the scapular spine and to the dorso-cranial aspect of the supraglenoid tubercle. The plate was placed onto the scapula and positioned under the raised suprascapular nerve (Figure 4). The fracture was fixated using twelve $5 \mathrm{~mm}$ locking head screws. Seven locking head screws were placed into the head of the plate to engage the supraglenoid tubercle fracture fragment and five were placed into the plate shaft to engage the 
scapula (Figure 5). The incision was closed routinely in 3three layers, the surgical site covered and the gelding recovered from general anesthesia in the hydropool system. Postoperatively, the gelding was kept in a sling ${ }^{t}$ for one month to prevent recumbency until the surgical incision had healed. The gelding was treated with phenylbutazone ${ }^{r}(2.2 \mathrm{mg} / \mathrm{kg}$ PO BID for 3 days and $2.2 \mathrm{mg} / \mathrm{kg}$ PO SID for 16 days) and cefquinom ${ }^{\mathrm{b}}(1 \mathrm{mg} / \mathrm{kg}$ IV BID for 6 days) postoperatively. A hoof bandage with frog support was applied to the contralateral limb to prevent laminitis. Ten days postoperatively the gelding was weight bearing well on the affected limb. However, marked atrophy of the supraspinatus and infraspinatus muscles became apparent, causing an obvious scapulohumeral joint instability when bearing weight on the affected limb and a shortened cranial phase of the stride at the walk. Two weeks postoperatively the surgical incision had healed without complications. Radiographs obtained on days 11, 15 and 32 postoperatively showed that the fracture line was less visible suggesting good progression of fracture healing. There was no evidence of lysis around the screws, screw looseing, or implant failure. One month postoperatively the gelding was discharged with instructions for small paddock confinement, daily hand walking for six additional weeks, and a lameness re-examination by the private veterinarian before starting work at a trot and canter. Two years following plate removal the owner was contacted. He was satisfied with the treatment outcome. According to the owner the horse was sound at the walk, trot and canter and was being used for pleasure riding. The infraspinatus and supraspinatus muscle atrophy as well as the scapulohumeral joint instability had improved.

\section{Case 3}

A 1.7-year-old, 450kg Warmblood filly was presented to the Equine Hospital at the University of Zurich with a 3 week old, simple, articular fracture of the left supraglenoid tubercle with moderate cranio-ventral displacement of the fracture fragment.

\section{Case management}

Pre-medication, preoperative preparation, the anesthetic protocol and the fracture approach were as described in case 1 . The filly was placed into right lateral recumbency. The suprascapular nerve was identified running over the cranial aspect of the scapula, however was not manipulated. A 7-hole, left-sided DFLP ${ }^{\mathrm{a}}$ was contoured to the cranio-lateral surface of the scapula and supraglenoid tubercle, overbending the plate at the site of the suprascapular nerve coursing over the neck of the scapula, to prevent its compression. The DFLP ${ }^{\mathrm{a}}$ was 
fixated proximally to the cranio-lateral aspect of the scapular spine using $45 \mathrm{~mm}$ locking head screws. Two plate holes were left empty at the site of the suprascapular nerve and distally the plate head was fixated to the cranio-lateral aspect of the supraglenoid tubercle using six $5 \mathrm{~mm}$ locking head screws (Figure 7). The incision was closed routinely in 3 layers, the surgical site covered, and the filly recovered from general anesthesia in the hydropool system.

Postoperatively the filly was kept in a sling ${ }^{\mathrm{t}}$ for 14 days to prevent recumbency until the surgical incision had healed. The filly was treated with phenylbutazone ${ }^{\mathrm{r}}(2.2 \mathrm{mg} / \mathrm{kg}$ PO BID for 9 days and then SID for 7 days) and cefquinom ${ }^{\mathrm{b}}$ ( $1 \mathrm{mg} / \mathrm{kg}$ IV BID for 10 days). A frog support was applied to the contralateral limb to prevent laminitis. Ten days postoperatively the filly was pyrexic $\left(39.1^{\circ} \mathrm{C}\right)$; it showed poor weight bearing of the left forelimb and a swelling at the distal aspect of the incision. Hematology revealed a mild leukocytosis and a normal fibrinogen concentration. An ultrasound examination revealed a small pocket of hypoechoic fluid in the muscle layers at the distal aspect of the incision. The incision was opened distally and purulent fluid was drained. A bacteriological swab was obtained and submitted for culture. The infected incision was surgically debrided and lavaged. The implants were not exposed. Although there was no bacterial growth on culture, the antibiotic therapy was changed to marbofloxacine ${ }^{u}(2 \mathrm{mg} / \mathrm{kg}$ IV SID for 9 days and $3 \mathrm{mg} / \mathrm{kg}$ PO SID for 18 days). The swelling gradually resolved, weight bearing improved, the drainage decreased and the incision healed. Three weeks postoperatively, a repeat radiograph of the left shoulder revealed signs of progressive bone healing and intact implants. At this point the filly was fully weight bearing, showed no muscle atrophies or scapulohumeral joint instability. The filly was discharged from the hospital 27 days postoperatively with instructions of box stall confinement and daily hand walk for nine weeks.

\section{Follow-up and outcome}

Three months postoperatively a re-examination at the Equine Hospital was performed. Mild atrophy of the infraspinatus - and supraspinatus muscle had developed, however there were no signs of scapulohumeral joint instability. The filly had a mildly shortened cranial phase of the stride at a walk and was mildly lame at the trot. Radiographs of the left shoulder showed progressive fracture healing, with the fracture line being faintly visible and the implants intact. The filly was discharged home with instructions of paddock confinement for a further three months and a re-examination before training. Two years postoperatively the filly was being ridden, was sound at a walk, trot, and canter and was performing early show-jumping. The mild muscle atrophy had resolved. 


\section{Discussion}

This report describes the use of DFLPs for the fixation of ST fractures. Because of the rigid tensile forces of the bicipital tendon, originating at the supraglenoid tubercle, strong fixation of this fracture type is required, which could be achieved, and is best achieved by application of the tension band principle. In each of the described cases the DFLP was placed in a different manner and avoidance of suprascapular nerve injury was attempted.

In humans DFLP are used for distal extra- and intra-articular supracondylar femur fractures in geriatric patients. The presence of osteoporosis, especially in elderly people, as well as comminution and intra-articular extension of the fracture line often makes a stable fixation challenging. However, with a minimally invasive plate osteosynthesis technique and with the use of the DFLP, a satisfactory result can be achieved in these patients (13-18). The advantages of using the DFLP in supraglenoid tubercle fractures in horses are the good stability of the implants and their ability to withstand the strong tensile forces exerted by the bicipital apparatus, where other implants have failed. There is also no need of partial or complete biceps tenotomy. The widened plate head allows placement of many screws into the fragment and the locking principle of the plate and screws Provides angle stability. The plate shaft allows placement of many screws over a large area of the scapular spine to provide better holding power in the porous scapula bone (9). For their original usw in human femoral fractures, the plates were designed as left- and right-sided. The main difference between leftand right-sided plates is in the bend along the plate shaft, which is needed to span the curved of the human femur and in the slightly different shape of the plate head. In horses only short plates (5-7 holes) were used and the shaft was therefore rather straight for both left- and rightsided plates. Intra-operatively both the left and right-sided plates were available and the surgeon chose the plate that fitted best, independent of the side the supraglenoid tubercle fracture. This led to the right-sided supraglenoid tubercle fracture in case 2 being repaired with a left-sided plate.

Fracture reduction and anatomical reduction of the articular surface is important for a primary union without callus formation, however perfect anatomical reduction, especially in chronic fractures, can be difficult and perfect anatomical reduction of the articular surface may not always be possible, resulting in osteoarthritis. Intra-operatively, fracture reduction may be achieved by limb extension and flexion. Once reduced, a pointed reduction foreceps may be applied for temporary fixation prior to applying the plate. In long standing cases, opening of the scapulohumeral joint may be necessary to assit and check the fracture reduction. 
For horses intended for future athletic use, there should not be a large degree of infraspinatusand supraspinatus muscle atrophy because it results in scapulohumeral joint instability. Atrophy of the supraspinatus and infraspinatus muscles is a common complication of supraglenoid tubercle fractures $(6,10)$. It may occur in horses left untreated, following surgical removal of the fracture fragment or by inserting lag screws $(2,6,10)$. To prevent supraspinatus- and infraspinatus muscle atrophy, it is imperative not to cause injury to the suprascapular nerve intra-operatively. Damaging the suprascapular nerve may be more likely when using plates, as compared to using lag screws and tension band wiring, due to their larger size and greater bone surface contact area. Plates are much stronger under tension than under compression, so that in cases of supraglenoid tubercle fractures plates should be placed on the cranial aspect of the scapula to withstand the biceps brachialis tendon pull (19). This, however, is the site where the suprascapular nerve lies making it challenging to preserve the suprascapular nerve.

In all cases the LCP-principle was utilized so as to avoid placing direct pressure on the small suprascapular nerve branches underlying the plate. In case 1, atrophy of the infraspinatus muscle occurred. This is not surprising given that the plate was positioned caudal to the scapular spine, just over the suprascapular nerve branches innervating this muscle. In case 2 the suprascapular nerve was markedly damaged by the underlying plate. This was observed at the time of plate removal. In this case friction and compression between the nerve and the plate, as well as potential damage occurring when isolating the suprascapular nerve during surgery may have resulted in damage to the nerve that led to the marked atrophy of the supraspinatus- and infraspinatus muscles (20). In case 3, the suprascapular nerve was not manipulated and the plate was overbent at the site of the suprascapular nerve resulting in barely any supraspinatus and infraspinatus muscle atrophy. When using LCP, the plate does not have to be precisely shaped to the bone to still provide optimal stability, however overbending should be performed gently and unidirectional, so as not to damage the plate or Combi holes (21).

In conclusion DFLP provided stable fixation of supraglenoid tubercle fractures in three cases. Care must be taken not to impinge the suprascapular nerve during the surgical procedure and when positioning the plate. Placement of the DFLP cranially to the scapular spine and with slightly overbending had the best outcome in one case. Further cases investigating the degree of muscle atrophy and evidence of scapulohumeral joint instability following the use of DFLP to repair supraglenoid tubercle fractures are needed, to improve patient outcome. 


\section{Acknowledgements}

Our thanks to Matthias Haab for the illustrations.

\section{Conflict of interest}

There are no conflicts of interests to report and no external funding was received.

\section{Footnotes}

a : Distal femoral locking plate ${ }^{\mathrm{TM}}$, DePuy Synthes $\mathrm{GmbH}$, Oberdorf, Switzerland

${ }^{\mathrm{b}}$ : Cobactan $^{\mathrm{TM}}$, Veterinaria AG, Freienbach, Switzerland

${ }^{\mathrm{c}}$ : Butadion ${ }^{\mathrm{TM}}$, Streuli Pharma AG, Uznach, Switzerland

${ }^{\mathrm{d}}$ : Prequillan ${ }^{\mathrm{TM}}$, ad us. vet., Arovet AG, Dietikon, Switzerland

${ }^{\mathrm{e}}$ : Domitor ${ }^{\mathrm{TM}}$, ad us. vet., Provet AG, Lyssach b. Burgdorf, Switzerland

${ }^{\mathrm{f}}$ : Narketan ${ }^{\mathrm{TM}} 10$ ad us. vet., Vétoquinol AG, Belp, Switzerland

g: Valium ${ }^{\mathrm{TM}} 10 \mathrm{mg}$, Roche Pharma Switzerland AG, Reinach, Switzerland

${ }^{\mathrm{h}}$ : Attane ${ }^{\mathrm{TM}}$ Isoflurane ad us. vet., Minrad INC., Buffalo, NY, USA

${ }^{\mathrm{i}}$ : Dobutrex ${ }^{\mathrm{TM}}$, Medika AG, Aesch, Switzerland

${ }^{\mathrm{j}}$ : Ringer-Lactat Bichsel ${ }^{\mathrm{TM}}$, Grosse Apotheke Dr. G. Bichsel AG, Interlaken, Switzerland

${ }^{\mathrm{k}}$ : HAES $10 \%^{\mathrm{TM}}$, Kantonsapotheke Zürich, Zürich, Switzerland

${ }^{1}: 3 \mathrm{M}$ Ioban $^{\mathrm{TM}} 2$, Health Care, St. Paul, USA

${ }^{\mathrm{m}}$ : Tensospray ${ }^{\mathrm{TM}}$, BSN medical GmbH, Hannover, Germany

${ }^{\mathrm{n}}$ : Isoelast ${ }^{\mathrm{TM}}$, IVF Hartmann AG, Neuhausen, Switzerland

${ }^{\mathrm{o}}$ : Slim body skin stapler $35 \mathrm{~W}^{\mathrm{TM}}$, Covidien, Mansfield, USA

${ }^{\mathrm{p}}$ : Vaseline album ${ }^{\mathrm{TM}}$, Hänseler AG, Herisau, Switzerland

${ }^{\mathrm{q}}$ : Morphin HCL 10mg, Sintetica SA, Mendrisio, Switzerland

${ }^{\mathrm{r}}$ : Butasan ${ }^{\mathrm{TM}}$, Vétoquinol AG, Ittingen, Switzerland

${ }^{\mathrm{s}}$ : Rota-TS ${ }^{\mathrm{TM}}$ Oraldoser ad us. vet., Vétoquinol AG, Ittingen, Switzerland

${ }^{\mathrm{t}}$ : GTRD, Ruedi Keller, Embrach and Heliseilerei Wyder, Erstfeld, Switzerland

${ }^{\mathrm{u}}:$ Forcyl $^{\mathrm{TM}}$, Vétoquinol AG, Ittigen, Switzerland 


\section{Figures}

Figure 1: Image of a stainless steel distal femoral locking plate (middle left: side and top views; middle right: bottom views). Seven locking head screws or cortex screws can be inserted into the head of the plate and five into the shaft of the plate.

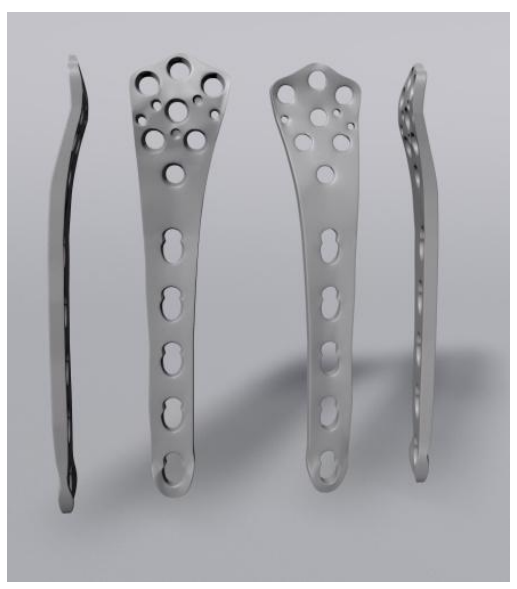

Figure 2: Preoperative medio-lateral radiograph of the left shoulder of case 1 showing the supraglenoid tubercle fracture.

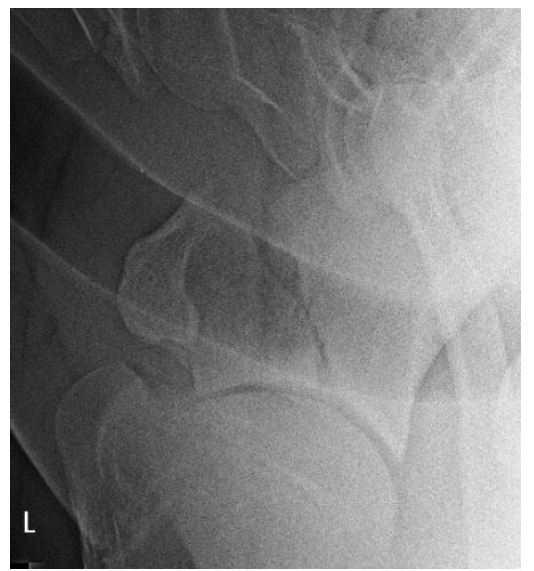


Figure 3A: Medio-lateral radiograph of the supraglenoid tubercle fracture 17 days postoperatively repaired with a distal femoral locking plate (Case 1).

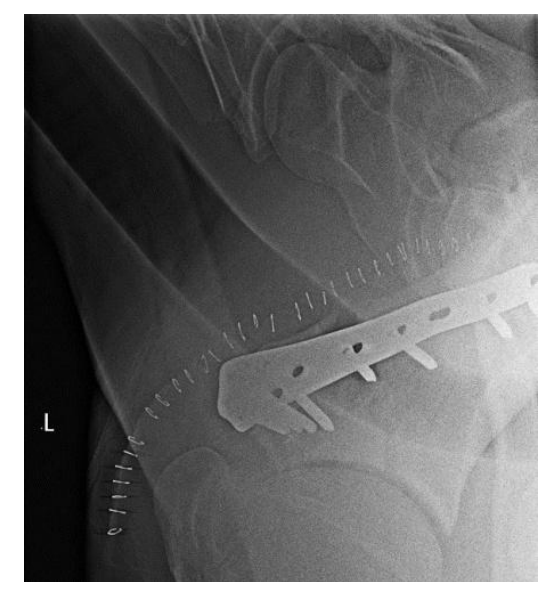

Figure 3B: Schematic lateral view of the scapula with the distal femoral locking plate placed caudal to the scapular spine as in case 1 .

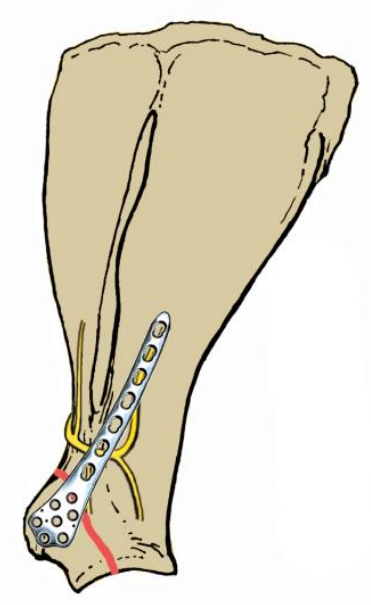


Figure 4: Intra-operative image showing placement of the distal femoral locking plate placed under the suprascapular nerve. The suprascapular nerve is visible, raised by a narrow Penrose drain over the plate shaft just at the proximal extent of the incision.

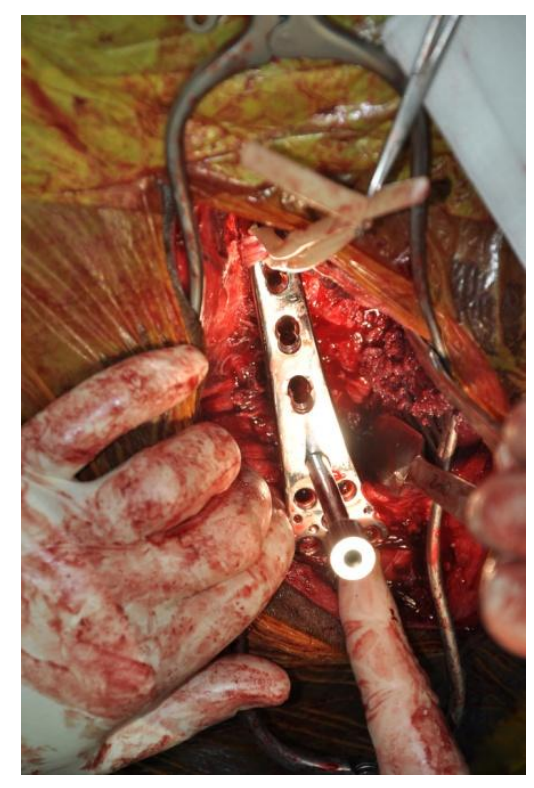

Figure 5A: Medio-lateral radiograph of the supraglenoid tubercle fracture of case 2 five days postoperatively, repaired with a distal femoral locking plate.

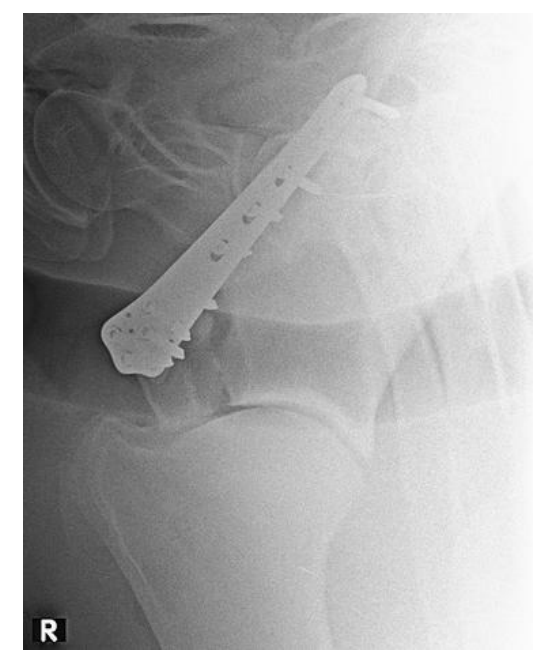


Figure 5B: Schematic lateral and cranial view of the scapula with the distal femoral locking plate placed under the suprascapular nerve as in case 2 .
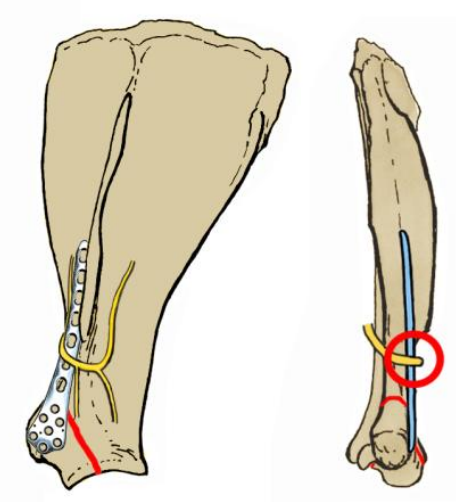

Figure 6: Marked supraspinatus and infraspinatus muscle atrophy of case 2 eight months following fracture fixation.

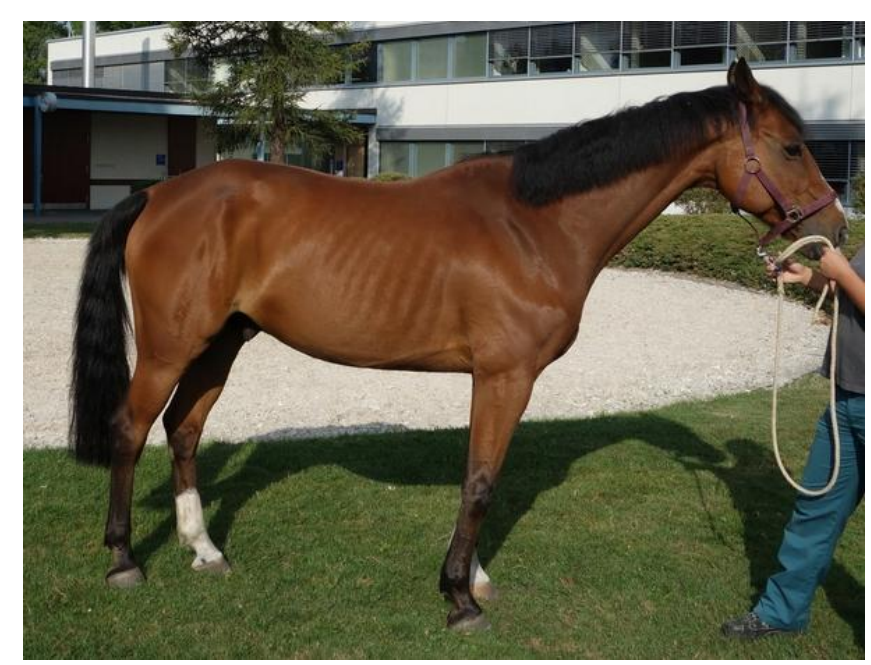


Figure 7A: Medio-lateral radiograph of the supraglenoid tubercle fracture of case 3 three weeks postoperatively repaired with a distal femoral locking plate.

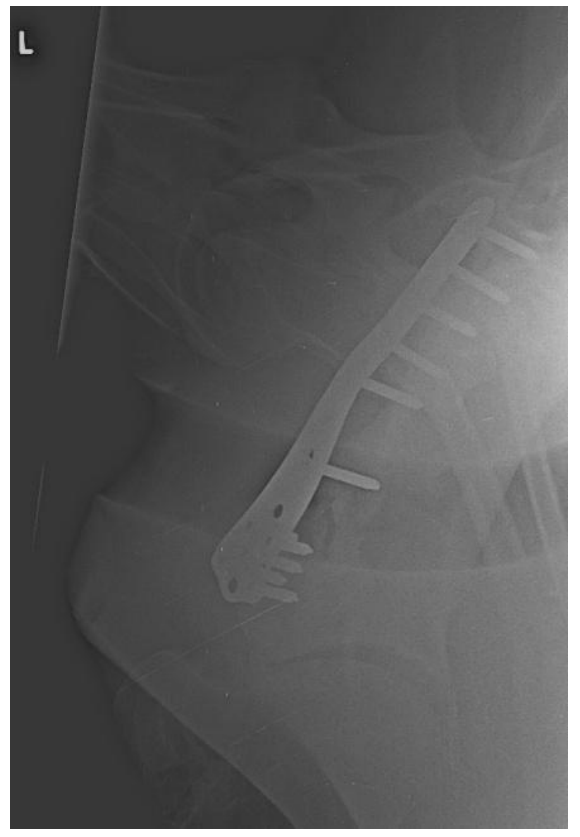

Figure 7B: Schematic lateral and cranial view of the scapula with the distal femoral locking plate placed over the suprascapular nerve as in case 3 .
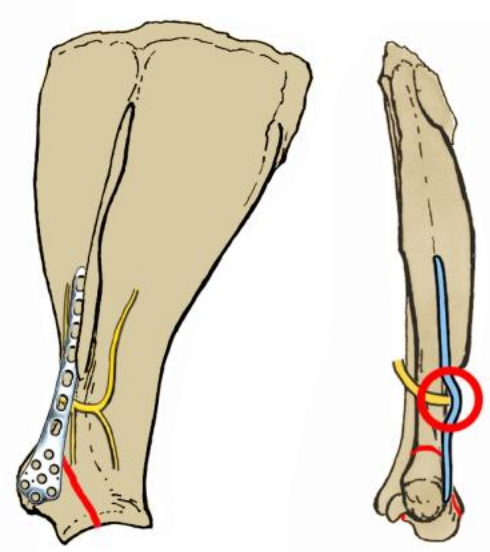


\section{References}

1. Leitch M. Review of treatment of tuber scapulae fractures in the horse. Journal of Equine Medicine and Surgery 1977; 1: 234-240.

2. Wagner PC, Watrous BJ, Shires GM, Riebold TW. Resection of the supraglenoid tubercle of the scapula in a colt. Comp Cont Educ Pract Vet 1985; 7: 36-41.

3. Adams SB. Surgical repair of a supraglenoid tubercle fracture in a horse. J Am Vet Medical Assoc 1987; 191: 332-334.

4. Fortier LA. Shoulder. In: Auer JA, Stick JA, editors. Equine Surgery. 4th edition. Missouri: Elsevier Saunders; 2012.pg. 1379-1387.

5. Stashak TS. Lahmheit. In: Stashak TS, editor. Adams Lahmheit bei Pferden. 4. Auflage. Hannover: M. \& H. Schaper; 2010. pg. 486 - 785.

6. Dyson S. Sixteen fractures of the shoulder region in the horse. Eq Vet J 1985; 17: 104110 .

7. Myers V, Burt J. The radiographic location of epiphyseal lines in equine lims. Proc Am Ass equine Pract 1966; 12: 21-39.

8. Pankowski RL, Grant BD, Sande R, Nickels FA. Fracture of the supraglenoid tubercle treatment and results in five horses. Vet Surg 1986; 15: 33-39.

9. Bleyaert HF, Sullins KE, White NA. Supraglenoid tubercle fractures in horses. Comp Cont Educ Pract Vet 1994; 16: 531-537.

10. Dart AJ, Snyder JR. Repair of a supraglenoid tuberosity fracture in a horse. J Am Vet Med Assoc. 1992; 201: 95-96.

11. Mez JC, Dabareiner RM, Cole RC, Watkins JP. Fractures of the greater tubercle of the humerus in horses: 15 cases (1986-2004). J Am Vet Med Assoc 2007; 230: 13501355.

12. Bleyaert HF, Madison JB. Complete biceps brachii tenotomy to facilitate internal fixation of supraglenoid tubercle fractures in three horses. Vet Surg 1999; 28: 48-53.

13. Doshi HK, Wenxian P, Burgula MV, Murphy DP. Clinical outcomes of distal femoral fractures in the geriatric population using locking plates with minimally invasive approach. Geriatr Orthop Surg Rehabil 2013; 4: 16-20.

14. Khursheed O, Wani MM, Rashid S, Lone AH, Manaan Q, Sultan A, et al. Results of treatment of distal extra: articular femur fractures with locking plates using minimally invasive approach-experience with 25 consecutive geriatric patients. Musculoskelet Surg 2015. 99: 139-147. 
15. Smith JR, Halliday R, Aquilina AL, Morrison RJ, Yip GC, McArthur J, et al. Distal femoral fractures: The need to review the standard of care. Injury 2015. 46: 10841088 .

16. Syed AA, Agarwal M, Giannoudis PV, Matthews SJ, Smith RM. Distal femoral fractures: long term outcome following stabilisation with the LISS. Injury 2004; 35: 599-607.

17. Kregor PJ, Stannard J, Zlowodzki M, Cole PA, Alonso J. Distal femoral fracture fixation utilizing the Less Invasive Stabilization System (L.I.S.S.): the technique and early results. Injury 2001; 32: 32-47.

18. Weight M, Collinge C. Early results of the less invasive stabilization system for mechanically unstable fractures of the distal femur (AO/OTA types A2, A3, C2, and C3). J Orthop Trauma 2004; 18: 503-508.

19. Auer JA. Principles of Fracture Treatment. In: Auer JA, Stick JA, editors. Equine Surgery. 4th edition. Missouri: Elsevier Saunders; 2012. pg. 1047-1080.

20. MacKay RJ. Peripheral Nerve Injury. In: Auer JA, Stick JA, editors. Equine Surgery. 4th edition. Missouri: Elsevier Saunders; 2012. pg. 720-727.

21. Texhammar R. AO-Instrumentierung. In: Texhammar R, Colton C, editors. AOInstrumente und -Implantate. 2. Auflage. Berlin: Springer; 2011. pg. 49-433. 


\section{Danksagung}

Ich möchte mich an dieser Stelle ganz herzlich bei meiner Betreuerin Andrea Bischofberger bedanken. Sie hat mir die Idee dieser Arbeit überlassen und mich von Anfang an mit grossem Engagement begleitet und war jederzeit mit Rat und Tat für mich da. Ihre fachliche und menschliche Unterstützung war für mich dieser Zeit von unglaublich grossem Wert und ohne sie wäre diese Arbeit nicht möglich gewesen. Besonders danken möchte ich ihr für die Freundschaft die für mich daraus entstanden ist und, so hoffe ich sehr, auch darüber hinaus bestehen bleibt.

Ebenfalls ganz herzlich möchte ich mich bei Prof. Anton Fürst für das Überlassen des sehr interessanten Grundgedankens zu dieser Arbeit, für die Übernahme des Referates, die sehr hilfreichen Korrekturen und Besprechungen des Manuskripts und auch für die wertvollen Gespräche, die dadurch entstanden sind, bedanken. Diese haben mir in dieser Zeit viel Motivation gegeben, meinen Weg zu gehen und ich werde gerne daran zurückdenken.

Muriel Sacks möchte ich danke sagen für die genaue Korrektur und Kommentare zum Manuskript.

Bei Matthias Haab möchte ich mich bedanken für die schönen grafischen Darstellungen.

Mein besonderer Dank gilt meiner Familie und meinem Verlobten für die bedingungslose Unterstützung auf meinem Weg in jeder Lebenslage. 


\section{Curriculum Vitae}

Vorname Name

Geburtsdatum

Geburtsort

Nationalität

Heimatort bei Schweizern

August/2000-September/2006

7. September 2006

September/2007 - Januar/2013

22. Januar 2013

Februar/2015 - Juli/2016

April/2013 - April/2015

April/2015 - Mai/2016

Juli 2016
Sina Sarah Frei

25.08.1986

Bülach ZH

$\mathrm{CH}$

Kloten ZH

Kantonsschule Zürcher Unterland, Bülach, Schweiz

Matura, Kantonsschule Zürcher Unterland, Bülach, Schweiz

Studium der Veterinärmedizin, Schwerpunkt Pferd, Vetsuisse-Fakultät, Universität Zürich, Schweiz

Abschlussprüfung vet. med., Vetsuisse-Fakultät, Universität Zürich, Schweiz

\section{Anfertigung der Dissertation}

unter Leitung von Prof. Anton Fürst und

Dr. med. vet. Andrea Bischofberger, Departement für Pferde, Klinik für Pferdechirurgie, Vetsuisse-Fakultät, Universität Zürich

Direktor: Prof. Anton Fürst

Assistenztierärztin/Internship, Departement für Pferde, Vetsuisse-Fakultät, Universität Zürich, Schweiz

Assistenztierärztin, Tierarztpraxis Josseck, Dr. med. vet. FVH für Pferde Henriette Josseck, Mörschwil, Schweiz

Tierärztin und Teilhaberin, Tierarztpraxis Handke + Frei, Grüsch, Schweiz 